\title{
KEDUDUKAN HAK IMUNITAS ADVOKAT DI INDONESIA
}

\author{
Fenny Cahyani, Muhammad Junaidi, Zaenal Arifin, Kadi Sukarna \\ Magister Hukum Universitas Semarang, Semarang \\ advokatfenny@gmail.com
}

\begin{abstract}
Abstrak
Penelitian tentang hak imunitas advokat ini bertujuan untuk mengetahui sejauh mana hak imunitas advokat diterapkan, apa kendalanya dan bagaimana solusinya. Undang-Undang Advokat mengakui hak imunitas advokat secara terbatas yaitu diatur dalam Pasal 14, Pasal 15, Pasal 16 Undang-Undang Advokat Nomor 18 Tahun 2003 tentang Advokat di mana sentral daripada pasal-pasal tersebut adalah dalam Pasal 16. Hak Imunitas yang ada dalam UU Advokat tersebut kemudian diperkuat dengan Putusan Nomor 26/PUUXI/2013 dengan diakuinya dan dijaminnya perlindungan terhadap Advokat dalam tindakan-tindakan non-litigasi yang dilakukan dengan iktikad baik dan untuk kepentingan pembelaan klien di dalam maupun di luar pengadilan. Di dalam praktek penegakan hukum, banyak advokat yang menyalahgunakan hak imunitas ini dan demikian pula sebaliknya banyak penegak hukum lain yang belum paham tentang hak imunitas advokat. Penelitian ini ini menggunakan pendekatan yuridis normatif. Hasil penelitian menyimpulkan bahwa penerapan hak imunitas berhasil apabila antar lembaga penegak hukum bekerja sesuai marwah undang-undang dan masing-masing pelaku hukum menjaga profesionalitas sesuai kode etik dan berpegang teguh pada asas iktikad baik untuk menjunjung tinggi hukum dan keadilan agar bermanfaat bagi masyarakat luas.
\end{abstract}

\section{Kata Kunci : Advokat; Hak Imunitas; Kode Etik.}




\title{
THE POSITION OF ADVOCATE IMUNITY RIGHTS IN INDONESIA
}

\begin{abstract}
This research on the immunity rights of advocates aims to determine the extent to which the rights of advocates immunity are applied, what are the obstacles and how the solutions are. The Advocate Law recognizes the limited right of advocates' immunity, which is regulated in Article 14, Article 15, Article 16 of the Advocate Law Number 18 of 2003 concerning Advocates and the central of these articles is in Article 16. The Advocate's rights that mention in this Advocate Law then strengthened by Decision Number 26/PUU-XI/2013 by recognizing and guaranteeing the protection of Advocates in non-litigation actions carried out in good faith and for the benefit of the client's defense inside and outside the court. At the practice of law enforcement, there are many advocates who abuse this right of immunity and vice versa, many other law enforcers do not understand about this immunity rights. This research uses a normative juridical approach. The results of the study concluded that the implementation of immunity rights is successful if between law enforcement agencies work in accordance with the spirit of the law and each legal actor maintains professionalism according to the code of ethics and adheres to the principle of good faith to uphold law and justice in order to benefit the wider community.
\end{abstract}

Keywords: Advocate; Immunity Rights; Code of Ethics. 


\section{A. PENDAHULUAN}

Pasal 1 ayat (1) Undang-Undang Advokat menyebutkan bahwa, "Advokat adalah orang yang berprofesi memberi jasa hukum, baik di dalam maupun di luar pengadilan yang memenuhi persyaratan berdasarkan undang-undang ini”. Selanjutnya ditegaskan dalam Pasal 5 ayat (1) Undang-Undang Advokat bahwa "Advokat adalah penegak hukum, bebas dan mandiri yang dijamin oleh hukum dan peraturan perundang-undangan". Bahwa dengan demikian telah tegas disebutkan bahwa kedudukan advokat adalah sejajar dengan polisi, jaksa dan hakim sebagai catur wangsa penegak hukum. Marwah yang demikian adalah marwah konstitusi yaitu sebagaimana disebutkan dalam Pasal 24 ayat (3) UUD 1945 yang mengatakan bahwa badan-badan lain yang fungsinya berkaitan dengan kekuasaan kehakiman diatur dalam undang-undang. Undang-Undang yang dimaksud di sini adalah Undang-Undang Nomor 48 tahun 2009 tentang Kekuasaan Kehakiman.

Peran advokat dalam tugas dan profesinya sebagai penegak dan penasehat hukum mempunyai tugas yang mulia dan strategi dalam pelaksanakan bantuan hukum, terutama untuk mewujudkan prinsip equality before the law dan presumption of innocence. Pasal 37 UU No. 14 Tahun 1970dan Pasal 56 ayat (2) KUHAP mengatur bahwa "penasehat hukum sebagai pihak yang memberikan bantuan hukum". ${ }^{1}$

Advokat mempunyai hak dan kewajiban dalam menjalankan profesinya sesuai Undang-Undang Advokat dan Kode Etik Advokat Indonesia. Salah satu hak yang melekat pada advokat adalah hak imunitas. Undang Undang Advokat telah menegaskan bahwa "setiap advokat memiliki hak untuk mendapatkan kekebalan atau hak imunitas dalam menjalankan tugas profesinya”. Advokat dalam menjakankan tugas dan profesinya "dapat melakukan atau tidak melakukan tindakan yang dianggap perlu, dapat memberikan pendapat serta berhak mendapatkan keterangan atau dokumen dari siapapun, tanpa harus menanggung konsekuensi hukum yang didapat dari pelaksanaan tugas profesinya". Advokat dan kliennya tidak boleh ditekan, diancam, mengalami hambatan, ketakutan atau perlakuan yang

\footnotetext{
${ }^{1}$ Patria Palgunadi, "Reposisi Bantuan Hukum Secara ProbonoOleh Organisasi Bantuan Hukum Dalam Kajian Undang-Undang Nomor 16 Tahun 2011 Tentang Bantuan Hukum”, Jurnal USM Law Review 1 (2),
} 2018, hlm. 202-215. DOI : $\underline{10.26623 / j u l r . v 1 i 2.2253}$ 
e-ISSN : 2621-4105

merendahkan harkat dan martabat profesi advokat. ${ }^{2}$ Selama advokat menjalankan tugas sesuai dengan tugas yang didelegasikan kepadanya sesuai dengan kuasa yang diberikan kepadanya dengan tetap mengindahkan aturan hukum undang-undang serta dilakukan sesuai profesionalitas advokat, maka advokat tersebut tidak dapat dituntut baik secara perdata maupun pidana.

Undang-Undang Advokat mengakui hak imunitas secara terbatas, yang diatur dalam Pasal 14, Pasal 15, Pasal 16 Undang-Undang Advokat Nomor 18 Tahun 2003. Sentral daripada pasal-pasal tersebut adalah Pasal 16 Undang-Undang Nomor 18 Tahun 2003 tentang Advokat. Hak Imunitas yang ada dalam UU Advokat tersebut kemudian diperkuat dengan Putusan Nomor 26/PUU-XI/2013, dimana Mahkamah Konstitusi menambahkan interpretasi baru yang memiliki kekuatan hukum penuh yang mengikat terhadap hak imunitas advokat. Inti amar putusan tersebut adalah "diakuinya dan dijaminnya perlindungan terhadap Advokat dalam tindakan-tindakan non-litigasi yang dilakukan dengan iktikad baik dan untuk kepentingan pembelaan klien di dalam maupun di luar pengadilan".

Pada prakteknya terdapat kasus di mana advokat dianggap menghalanghalangi hukum (obstruction of justice), contohnya kasus advokat Firman Wijaya di mana pada saat menjalankan tugasnya sebagai seorang advokat yang mewakili klien dalam persidangan telah dilaporkan ke kepolisian oleh pihak yang merasa nama baiknya dicemarkan. Satu sisi, terdapat kasus advokat yang dilaporkan ke kepolisian pada saat menjalankan tugasnya dalam rangka membela kepentingan klien dengan iktikad baik, di sisi yang lain kerap kali advokat menggunakan hak imunitas advokat yang telah diberikan kepada undang-undang dengan tanpa mengindahkan iktikad baik dan profesionalitas advokat sebagaimana telah diatur dalam Kode Etik Advokat Indonesia. Banyak advokat yang "terjerumus" dalam menggunakan hak ini pada saat mendampingi klien. Lihat saja kasus Advokat Manatap Ambarita (2008), Advokat Lambertus Palangana (2010), Advokat Haposan Hutagalung (2011), Advokat Fredrich Yunadi (2018) dan yang terbaru sekali adalah kasus Advokat Eggi Sudjana (2019) yang bersikeras bahwa sebagai seorang advokat dia tidak dapat dituntut dalam perkara pidana ataupun perdata tanpa mengindahkan kasus sebenarnya yang disangkakan kepadanya.

${ }^{2}$ H.P Panggabean, “Manajemen Advokasi”, (Alumni, Jakarta, 2010), hlm. 151. 
Penelitian tentang hak imunitas advokat telah banyak dilakukan oleh penelitipeneliti terdahulu, sebagai contoh yaitu penelitian Pratiwi (2019) dengan judul “Analisis tentang Hak Imunitas Hukum Profesi Advokat Dalam Penanganan Kasus Pidana" yang berfokus pada perkara pidana yang menimpa advokat Fredrick Yunadi dalam penanganan perkara pidana terkait kasus Setyo Novanto. ${ }^{3}$ Kelebihan penelitian ini adalah membahas mengenai penerapan hak imunitas advokat dalam penanganan perkara pidana akan tetapi belum menyentuh mengenai bagaimana kendala dalam penerapan hak imunitas advokat baik kendala dalam penanganan perkara pidana maupun kendala dalam penegakan hukum oleh advokat secara luas.

Penelitian lainnya adalah peneltian oleh Dharma (2018) yang menganalisis tentang hak imunitas advokat dalam persidangan tindak pidana korupsi, di mana dalam penelitian ini membahas mengenai hak imunitas advokat dalam hal advokat tersebut terkena kasus pidana korupsi. Dalam penelitian ini sudah menjabarkan tentang letak dan pengaturan hak imunitas advokat yang ada dalam Undang-Undang Advokat akan tetapi dalam pembahasanya khusus hanya mengenai advokat yang terkena pasal tindak pidana korupsi. ${ }^{4}$

Sedangkan penelitian yang dilakukan oleh Arif (2018) berfokus pada kode etik advokat Indonesia serta penerapan kode etik tersebut, hambatan dalam melaksanakan hak imunitas advokat dan perannya dalam proses penegakan hukum dan hak entitas advokat sebagai penegak hukum yang bebas dan mandiri. ${ }^{5}$ Dalam penelitian ini banyak membahas kode etik profesi advokat serta peran hak imunitas bagi advokat agar dapat melakukan pekerjaannya sebagai penegak hukum yang bebas dan mandiri akan tetapi belum dibahas mengenai kendala dan solusi dalam penerapan hak imunitas advokat tersebut.

Penelitian yang dilakukan oleh peneliti-peneliti terdahulu lebih kepada kasus per kasus dengan meneliti putusan pidana yang menimpa sejumlah advokat di kota tertentu sedangkan penelitian ini lebih mengkhususkan kepada penerapan hak imunitas advokat di Indonesia secara umum menurut Undang-Undang Advokat

\footnotetext{
${ }^{3}$ Dita Tania Pratiwi, Manertiur Maulana Lubis, "Analisis Tentang Hak Imunitas Hukum Profesi Advokat Dalam Penanganan Kasus Pidana”, Jurnal Adil 10 (2), 2019, hal. 17. DOI: https://doi.org/10.33476/ajl.v10i2.1227

${ }^{4}$ Ida Wayan Dharma dkk, "Hak Imunitas Advokat dalam Persidangan Tindak Pidana Korupsi ”, Jurnal Kerthawicara 7 (5), 2018, hal. 11.

${ }^{5}$ Kamal Arif, "Perlindungan Hukum Terhadap Hak Imunitas Advokat dalam Penegakan Hukum di Indonesia”, Jurnal Surya Keadilan 2 (1), 2018, hal. 274-288.
} 
e-ISSN : 2621-4105

Indonesia Nomor 18 Tahun 2003. Tujuan penelitian ini adalah untuk menganalisa penerapan hak imunitas advokat serta menganalisa kendala dan mengkaji solusi atas penerapan hak imunitas advokat sesuai dengan Undang-Undang Nomor 18 Tahun 2003 tentang Advokat.

\section{B. PERMASALAHAN}

1. Bagaimana penerapan hak imunitas advokat sesuai Undang Undang Nomor 18 Tahun 2003 Tentang Advokat?

2. Bagaimana kendala dan solusi atas penerapan hak imunitas advokat sesuai Undang Undang Nomor 18 Tahun 2003 Tentang Advokat?

\section{METODE PENELITIAN}

Pendekatan yang digunakan dalam penelitian ini adalah pendekatan yuridis normatif yaitu "pendekatan dari segi peraturan perundang-undangan dan normanorma hukum sesuai dengan permasalahan yang ada dengan cara meneliti bahan pustaka atau data sekunder". Spesifikasi penelitian ini adalah deskriptif analistis, yaitu "menggambarkan peraturan perundang-undangan yang berlaku dikaitkan dengan teori-teori hukum dan praktek pelaksanaan hukum positif yang menyangkut permasalahan di atas”. Adapun sumber dan jenis data yang digunakan dalam penelitian ini adalah "data sekunder yang diperoleh dari bahan hukum yang terdiri dari bahan hukum primer, bahan hukum sekunder dan bahan hukum tertier”. Teknik pengumpulan data dilakukan dengan cara penelitian kepustakaan (library research), yaitu "penelitian yang dilakukan dengan cara meneliti bahan pustaka atau yang disebut data sekunder”. Teknik analisis data yang digunakan adalah kualitatif normatif, yaitu "data yang diperoleh disusun secara sistematis kemudian dianalisis secara kualitatif normatif agar dapat diperoleh kejelasan masalah yang dibahas". Tujuan digunakannya analisa ini adalah "untuk mendapatkan pandangan-pandangan mengenai pelaksanaan peraturan perundang-undangan di Indonesia yang mengatur tentang implementasi Undang Undang no. 18 tahun 2003 tentang Advokat sehungga pada akhirnya akan didapatkan kerangka pembahruan hukum berkaitan dengan masalah penerapan hak imunitas advokat". 


\section{HASIL DAN PEMBAHASAN}

1. Penerapan Hak Imunitas Advokat Menurut Undang Undang Nomor 18 Tahun 2003 tentang Advokat

Advokat sebagai " penegak hukum merupakan profesi yang rentan dari berbagai intervensi kepentingan, longgarnya profesi advokat dari ikatan kepercayaan, dan tentu saja, pengawasan masyarakat". 6 Imunitas yang diperlukan oleh Advokat dalam melaksanakan fungsi dan tugasnya diatur berdasarkan Undang-Undang Nomor 18 Tahun 2003 tentang Advokat (UU Advokat), yang di dalam konsideran menjelaskan bahwa "advokat dalam menjalankan profesinya bebas, mandiri, dan bertanggung jawab dalam menegakkan hukum, dan dilindungi oleh undang-undang demi terselenggaranya upaya penegakan supremasi hokum". Salah satu jaminan yang diberikan UU Advokat kepada advokat yaitu advokat tidak dapat dituntut baik secara perdata maupun pidana dalam menjalankan tugas profesinya. ${ }^{7}$

Dalam hal penerapan hak imunitas advokat di Indonesia maka perlu dilihat tiga komponen yang telah disebutkan dalam Teori Friedman tersebut yaitu teori istem hukum sendiri terdiri atas tiga komponen yaitu struktur hukum (berupa lembaga hukum); substansi hukum (peraturan perundang-undangan); dan kultur hukum atau budaya hukum.

Dalam penerapan hak imunitas advokat, lembaga yang terlibat secara langsung adalah kepolisian, kejaksaan, pengadilan serta advokat itu sendiri. Masing-masing lembaga penegak hukum ini harus senantiasa menghormati tugas dan fungsi masing-masing lembaga. Kepolisian dalam melakukan penyelidikan/penyidikan, kejaksaan dalam hal melakukan penuntutan, advokat dalam hal melakukan pembelaan maupun mengajukan gugatan keperdataan, masing-masing lembaga ini harus tunduk dan patuh pada ketentuan perundangundangan.

${ }^{6}$ Oey Valentino Winata, Wisnu Aryo Dewanto, “BatasanTerhadap Imunitas Advokat Yang Diperluas Berdasarkan Putusan Mahkamah Konstitusi Nomor 26/PUU-XI/2013”, DiH: Jurnal Ilmu Hukum 16 (1), 2020, hal 38-48.

DOI: https://doi.org/10.30996/dih.v16i1.2974

${ }^{7}$ Anwar Hafidzi, "Eksistensi Advokat Sebagai Profesi Terhormat (Officium Nobile) Dalam Sistem Negara Hukum Di Indonesia”, Khazanah: Jurnal Studi Islam Dan Humaniora 13(1), 2015, hal. 1-25. DOI: http://dx.doi.org/10.18592/khazanah.v13i1.517 
Menurut Soerjono Soekanto, ruang lingkup dari istilah "penegak hukum" sangat luas oleh karena mencakup mereka yang secara langsung dan secara tidak langsung berkecimpung di bidang penegakan hukum. Dari pengertian yang luas tadi, Soerjono Soekanto lebih membatasi pengertiannya yaitu "kalangan yang secara langsung berkecimpung dalam bidang penegakan hukum yang tidak hanya mencakup law enforcement, akan tetapi juga peace maintenance”. Dengan demikian mencakup mereka yang bertugas di bidang-bidang kehakiman, kejaksaan, kepolisian, kepengacaraan, dan pemasyarakatan. ${ }^{8}$

Berdasarkan hal-hal tersebut di atas maka dalam penerapan hak imunitas advokat, yang paling berperan penting dalam hal ini adalah aparatur penegak hukumnya, dalam hal aparatur penegak hukum berhasil menggerakkan sistem hukum secara dinamis maka akan melahirkan masyarakat yang patuh (obey) terhadap hukum.

Pengaturan peraturan perundang-undangan mengenai hak imunitas advokat telah jelas dan tegas disebutkan dalam Pasal 16 Undang-Undang Advokat Indonesia jo Putusan Mahkamah Konstitusi Nomor 26/PUU-XI/2013. Pelaksanaan penerapan hak imunitas advokat pun telah diatur dalam ruang lingkup UndangUndang Nomor 18 tahun 2003 tentang Advokat serta Kode Etik Advokat Indonesia. Baik dalam undang-undang advokat maupun kode etik advokat koridor yang paling penting adalah adanya iktikad baik dalam hal melaksanakan undang-undang.

Budaya hukum adalah "sikap mental yang menentukan bagaimana hukum digunakan, dihindari, atau bahkan disalahgunakan". Penerapan hak imunitas advokat dalam hal ini akan bergantung kepada individu masing-masing lembaga. Individu inilah yang berperan penting dalam hal apakah hukum/undang-undang itu akan digunakan secara bertanggung jawab ataukan akan disalahgunakan penerapannya.

Tiga nilai dasar hukum menurut Gustav Radburch meliputi; keadilan (filosofis), kepastian hukum (yuridis) dan kemanfaatan bagi masyarakat (sosiologis). Dalam teorinya sendiri, Gustav Radbruch menjelasakan bahwa "asas prioritas dari tiga nilai dasar yang menjadi tujuan hokum". Hal ini disebabkan

${ }^{8}$ Soerjono Soekanto, "Faktor-Faktor yang Mempengaruhi Penegakan Hukum”, (Jakarta: PT Raja Grafindo Persada, 2007), hal 19. 
karena dalam realitasnya, keadilan hukum sering berbenturan dengan kemanfaatan dan kepastian hukum dan begitupun sebaliknya. Diantara tiga nilai dasar tujuan hukum tersebut, pada saat terjadi benturan, maka mesti ada yang dikorbankan. Untuk itu, asas prioritas yang digunakan oleh Gustav Radbruch harus dilaksanakan dengan urutan sebagai berikut:

1. Keadilan Hukum;

2. Kemanfaatan Hukum;

3. Kepastian Hukum. ${ }^{9}$

Dengan urutan prioritas sebagaimana dikemukakan tersebut diatas, maka sistem hukum dapat terhindar dari konflik internal. ${ }^{10}$ Menurut Radbruch ketiga aspek ini sifatnya relatif, bisa berubah-ubah. "Satu waktu bisa menonjolkan keadilan dan mendesak kegunaan dan kepastian hukum ke wilayah tepi. Di waktu lain bisa ditonjolkan kepastian atau kemanfaatan”. Hubungan yang sifatnya relatif dan berubah ubah ini tidak memuaskan. Meuwissen memilih kebebasan sebagai landasan dan cita hukum. Kebebasan yang dimaksud bukan kesewenangan, karena kebebasan tidak berkaitan dengan apa yang kita inginkan. Tetapi berkenaan dengan hal menginginkan apa yang kita ingini. Dengan kebebasan kita dapat menghubungkan kepastian, keadilan, persamaan dan sebagainya ketimbang mengikuti Radbruch. ${ }^{11}$

Penerapan hak imunitas advokat menurut Undang-Undang Nomor 18 Tahun 2003 tentang Advokat sendiri apabila ditinjau dengan teori dasar hukum Gustav Radburch maka lebih kepada nilai keadilan dan kemanfaatan oleh karena untuk kepastian sendiri, hak imunitas sudah tegas dan jelas diatur dalam Pasal 16 Undang-Undang Nomor 18 Tahun 2003 tentang Advokat jo Putusan Mahkamah Konstitusi Nomor 26/PUU-XI/2013.

Di dalam keadilan terdapat aspek filosofis yaitu norma hukum, nilai, keadilan, moral, dan etika. Hukum sebagai pengemban nilai keadilan, nilai keadilan juga menjadi dasar dari hukum sebagai hukum. Keadilan memiliki sifat normatif sekaligus konstitutif bagi hukum. Keadilan menjadi landasan moral hukum dan

\footnotetext{
${ }^{9}$ Muhammad Erwin, “Filsafat Hukum”, Raja Grafindo, Jakarta, 2012, hal.12.

${ }^{10}$ Ahmad Zaenal Fanani, “Berpikir Falsafati Dalam Putusan Hakim”, Varia Peradilan No. 304 Maret 2011, hal. 3 .

${ }^{11}$ Sidharta Arief, "Meuwissen Tentang Pengembanan Hukum, Ilmu Hukum, Teori Hukum dan Filsafat Hukum”, (Bandung PT Refika Aditama, , 2007), hal. 20.
} 
sekaligus tolok ukur sistem hukum positif dan tanpa keadilan sebuah aturan tidak pantas menjadi hukum. ${ }^{12}$

Dengan mendasarkan teori keadilan dengan penerapan hak imunitas advokat maka penerapan hak imunitas advokat sudah seharusnya tidak mencederai rasa keadilan bagi pencari keadilan lainnya.

Penelitian dari Chairani (2018) menyimpulkan bahwa hak imunitas advokat tidak bersifat mutlak atau absolut. Advokat bukan merupakan profesi yang kebal hukum. Advokat merupakan profesi yang mulia yang harus secara profesional dalam menjalankan tugas dan profesinya dalam memberikan upaya hukum yang terbaik terhadap kliennya. ${ }^{13}$ Penelitian Chairani tersebut juga diperkuat oleh Sardinata (2021) dalam penelitiannya tentang hak imunitas advokat menguraikan bahwa dalam menangani suatu perkara hak imunitas advokat dapat berlaku di dalam atau diluar persidangan sebagaimana diatur dalam Pasal 16 UU Advokat. Tetapi dalam pelaksanaannya hak imunitas advokat tersebut dibatasi oleh iktikad baik. Hal ini berarti bahwa dalam menjalankan tugas dan profesinya advokat tidak mempunyai hak imunitas secara absolut sehingga bebas dari segala tuntutan hukum. ${ }^{14}$

Penjelasan Pasal 16 UU Advokat menjelaskan, bahwa yang dimaksud dengan iktikad baik adalah "menjalankan tugas profesi demi tegaknyakeadilan berdasarkan hukum untuk membela kepentingan kliennya”. Yang dimaksud dengan sidang pengadilan adalah "sidang pengadilan dalam setiaptingkat pengadilan di semua lingkungan peradilan". ${ }^{15}$

Bentham menemukan bahwa dasar yang paling objektif adalah "dengan melihat apakah suatu kebijakan atau tindakan tertentu membawa manfaat atau hasil yang berguna atau, sebaliknya kerugian bagi orang-orang yang terkait". ${ }^{16}$

12 Sakhiyatu Sova, “Tiga Nilai Dasar Hukum Menurut Gustav Radbruch", http://www.scrid.com/doc/170579596/Tiga-Nilai-Dasar-Hukum-Menurut-Gustav-Radbruch\#scridb, diakses pada tanggal 15 Juli 2019, pukul 12.09 WIB

${ }^{13}$ Mierza Aulia Chairani, "Hak Imunitas Advokat Terkait Melecehkan Ahli”, Justitia Jurnal Hukum 2(1), 144163. DOI: http://dx.doi.org/10.30651/justitia.v2i1.1236

${ }^{14}$ Sardinata, Hambali Thalib, Mulyati Pawennei, "Hak Imunitas Advokat Dalam Menangani Perkara”, Jurnal Lex Generalis 2 (3), 2021. hal. 1074-1086. DOI: https://doi.org/10.52103/jlg.v2i3

${ }^{15}$ Cinthia Wijaya, John Calvin, Mutiara Girindra Pratiwi, "Usaha Pemerintah Melindungi Hak Imunitas Advokat Dalam Melakukan Pekerjaan", RESAM Jurnal Hukum 5 (1), hal 40-56. https://doi.org/10.32661/resam.v5i1.16

${ }^{16}$ Sonny Keraf, "Etika Bisnis Tuntunan dan Relevansinya", (Yogyakarta Kanisius, 1998), hal. 93-94. 
e-ISSN : 2621-4105

Berdasarkan orientasi itu, maka isi hukum adalah ketentuan tentang pengaturan penciptaan kesejahteraan negara. ${ }^{17}$

Dengan menerapkan teori kemanfaatan berkaitan dengan apa yang dinyatakan Bentham maka "penerapan hak imunitas advokat harus diukur dari baik buruknya akibat yang dihasilkan oleh penerapan hukum itu. Suatu ketentuan hukum baru bisa di nilai baik, jika akibat-akibat yang dihasilkan dari penerapannya adalah kebaikan, kebahagiaan sebesar-besarnya dan berkurangnya penderitaan". Dan sebaliknya dinilai buruk jika penerapannya menghasilkan akibat-akibat yang tidak adil, kerugian, dan hanya memperbesar penderitaan. Penerapan hak imunitas advokat lebih menekankan kepada kemanfaatannya untuk penegakan hukum, menekankan kepada tujuan hukumnya dalam arti apa sebetulnya yang menjadi tujuan penerapan hak imunitas advokat, yaitu bahwa advokat dapat bekerja sesuai profesi hukumnya dalam rangka menegakkan kebenaran dan menjunjung tinggi hukum tanpa ada rasa takut dikriminalisasi dengan batasan asas iktikad baik.

\section{Kendala dan Solusi Penerapan Hak Imunitas Advokat}

Advokat dalam menjalankan tugas dan profesinya memerlukan hak imunitas mengingat advokat merupakan profesi yang mulia. Dengan mempunyai hak istimewa berupa hak imunitas agar dalam menjalan tugasnya advokat dapat secara bebas dan bertanggung jawab terhadap kliennya. Advokat juga harus dapat menjaga kewajibannya dan mempunyai tanggung jawab moral terhadap kehormatan profesinya. $^{18}$

Struktur hukum, substansi hukum dan budaya hukum sebagaimana disebutkan dalam teori LM Friedman yang paling berperan penting dalam penegakan hukum. Struktur hukum adalah lembaga-lembaga penegak hukumnya, substansi hukum adalah peraturannya sedangkan budaya hukum adalah kultur atau budaya dari masing-masing individu penegakan hukum dan masyarakat.

Kendala penerapan hak imunitas advokat dalam hal ke tiga sistem hukum tersebut adalah : Lembaga penegak hukum kepolisian, kejaksaan, kehakiman memandang sebelah mata terhadap profesi advokat dan belum menganggap

${ }^{17}$ Lili Rasjidi dan I.B Wyasa Putra, "Hukum sebagai Suatu Sistem”, (Bandung Remaja Rosdakarya, 1993), hal. 79-80.

${ }^{18}$ Muhammad Khambali, “Hak Imunitas Advokat Tidak Tak Terbatas” Jurnal Cakrawala Hukum,13 (1), 2017. 
advokat sebagai penegak hukum yang posisinya sejajar/setara dengan lembaga penegak hukum lain.

Solusi yang bisa dilakukan adalah masing-masing lembaga penegak hukum di luar advokat harus memahami profesi advokat sebagai profesi terhormat yang menegakkan hukum dan menjunjung tinggi kebenaran. Proses pemanggilan maupun penindakan terhadap advokat tetap mengedepankan undang-undang advokat tanpa mengesampingkan hukum acara.

Di satu sisi, advokat disebutkan sebagai penegak hukum, di sisi lain advokat tidak masuk ke dalam criminal justice system. Criminal justice system (sistem peradilan pidana) adalah "rangkaian proses bekerjanya lembaga-lembaga penegak hukum sebagai suatu sistem yang berupaya menemukan kebenaran materiil (law enforcement) atas suatu peristiwa hukum tindak pidana di masyarakat". Lembagalembaga yang masuk dalam criminal justice system ini adalah kepolisian, kejaksaan, kehakiman dan lembaga pemasyarakatan. Hal ini pada akhirnya mengakibatkan kesenjangan antara advokat dengan ketiga lembaga dalam sistem peradilan pidana tersebut, seolah-olah advokat dianggap sebagai pihak yang berseberangan dengan lembaga tersebut dalam hal peradilan pidana.

Solusi yang harus dilakukan adalah advokat harus masuk ke dalam criminal justice system sehingga wajib ada kehadiran seorang advokat untuk mengawal perkara dari dimulainya proses penyelidikan sampai tahap persidangan.

Advokat bekerja sesuai dengan kode etik, yang merupakan kaidah tertinggi yang harus dijunjung tinggi oleh advokat. Kode etik berkaitan dengan moral dan etika dari advokat yang pada akhirnya akan melahirkan budaya hukum yang seyogyanya menjunjung tinggi hukum dan keadilan. Dalam undang-undang advokat itu sendiri, advokat dalam membela klien dengan menerapkan kebenaran di atas segalanya bukan semata-mata karena diberi upah oleh klien. Hal ini belum menjiwai semangat semua advokat yang pada akhirnya tidak menerapkan kode etik dan menjaga marwah profesi advokat sebagai profesi terhormat (officium nobile). Solusi yang harus dilakukan adalah menegakkan kode etik di kalangan advokat, pembinaan terhadap advokat terkait kode etik. 
Gustav Radburch menetapkan asas prioritas dalam teorinya, yaitu berurutan keadilan hukum sebagai kaidah tertinggi kemudian kemanfaatan hukum menempati posisi kedua dan yang terakhir kepastian hukum. Kendala penerapan hak imunitas advokat lebih kepada asas keadilan dan kemanfaatan yaitu :

Keadilan melingkupi norma hukum, norma nilai, moral dan etika. Kendala yang ada adalah kerap kali nilai, moral dan etika dikesampingkan dalam hal penegakan hukum. Masing-masing lembaga penegak hukum kadang kala mengabaikan nilai-nilai moral dan etika. Solusi yang harus dilakukan adalah menjaga agar kode etik advokat, kode etik, polisi, kode etik jaksa dan kode etik hakim dapat dimaknai lebih dalam oleh masing-masing individu penegak hukum. Pembinaan terhadap kode etik juga perlu dilakukan.

Penegakan hukum harus bermanfaat kepada sebanyak-banyaknya masyarakat. Penegakan hukum dikatakan berhasil apabila manfaat dirasakan lebih banyak daripada kerugian yang didapat. Kendala dalam menerapkan hak imunitas advokat adalah penerapan hak imunitas advokat mempunyai dampak kepada banyak orang secara moral, manfaat yang dirasakan dalam penerapan hak imunitas advokat belum dapat dirasakan oleh masyarakat secara luas. Hal ini dikarenakan hak imunitas masih belum diterapkan dengan benar, masih banyak advokat yang salah menafsirkan atau bahkan menyalahgunakan hak ini.

Solusi yang harus dilakukan adalah advokat harus memahami manfaat apa yang seharusnya didapatkan masyarakat dengan menerapkan hak imunitas advokat, dalam hal ini apabila hak imunitas advokat diterapkan dengan benar maka dengan senjata inilah advokat dapat membela kliennya tanpa rasa takut, mengungkap sejatinya kebenaran yang ada dengan tetap berpegang teguh kepada koridor kode etik.

\section{E. PENUTUP}

Penerapan hak imunitas advokat harus menyentuh tiga komponen hukum berupa struktur hukum, substansi hukum dan budaya hukum sehingga dapat terwujud penegakan hukum yang berkeadilan, berkepastian dan bermanfaat bagi masyarakat luas. Penerapan hak imunitas advokat juga harus dapat membawa penegakan hukum ke arah keadilan, kemanfaatan dan kepastian. Kendala dalam 
penerapan hak imunitas advokat di Indonesia adalah antara penegak hukum tidak tercipta suatu hubungan yang simbiosis mutualisme dalam arti positif. Advokat sendiri banyak yang menyalahgunakan kewenangan hak imunitasnya oleh karena penafsiran yang salah tentang hak imunitas advokat. Hak imunitas advokat terbatas dalam koridor kode etik dan asas iktikad baik yang harus dijunjung tinggi oleh advokat. Solusinya adalah advokat harus masuk ke dalam criminal justice syatem agar kedudukan advokat benar benar setara dengan penegak hukum lainnya dan hubungan antar penegak hukum dapat berjalan seimbang.

\section{DAFTAR PUSTAKA}

\section{Buku}

H.P Panggabean, 2010, "Manajemen Advokasi", Alumni, Jakarta

Lili Rasjidi dan I.B Wyasa Putra, 1993, "Hukum sebagai Suatu Sistem”, Remaja Rosdakarya, Bandung.

Muhammad Erwin, 2012, "Filsafat Hukum”, Raja Grafindo, Jakarta,

Sidharta Arief, 2007, "Meuwissen Tentang Pengembanan Hukum, Ilmu Hukum, Teori Hukum dan Filsafat Hukum”, PT Refika Aditama, Bandung.

Soerjono Soekanto, 2007, "Faktor-Faktor yang Mempengaruhi Penegakan Hukum", PT Raja Grafindo Persada, Jakarta

Sonny Keraf, 1998, “Etika Bisnis Tuntunan dan Relevansinya”, Kanisius, Yogyakarta.

\section{Jurnal}

Anwar Hafidzi, "Eksistensi Advokat Sebagai Profesi Terhormat (Officium Nobile) Dalam Sistem Negara Hukum Di Indonesia", Khazanah: Jurnal Studi Islam Dan Humaniora 13(1), 2015.

DOI: http://dx.doi.org/10.18592/khazanah.v13i1.517

Cinthia Wijaya, John Calvin, Mutiara Girindra Pratiwi, "Usaha Pemerintah Melindungi Hak Imunitas Advokat Dalam Melakukan Pekerjaan”, RESAM Jurnal Hukum 5 (1), 2019.

https://doi.org/10.32661/resam.v5i1.16

Dita Tania Pratiwi, Manertiur Maulana Lubis, "Analisis Tentang Hak Imunitas Hukum Profesi Advokat Dalam Penanganan Kasus Pidana”, Jurnal Adil 10 (2), 2019. DOI: https://doi.org/10.33476/ajl.v10i2.1227

Ida Wayan Dharma dkk, "Hak Imunitas Advokat dalam Persidangan Tindak Pidana Korupsi”, Jurnal Kerthawicara 7 (5), 2018.

Kamal Arif, "Perlindungan Hukum Terhadap Hak Imunitas Advokat dalam Penegakan Hukum di Indonesia”, Jurnal Surya Keadilan 2 (1), 2018.

Mierza Aulia Chairani, "Hak Imunitas Advokat Terkait Melecehkan Ahli", Justitia Jurnal Hukum 2 (1), 2018.

DOI: http://dx.doi.org/10.30651/justitia.v2i1.1236 
e-ISSN : 2621-4105

Muhammad Khambali, "Hak Imunitas Advokat Tidak Tak Terbatas", Jurnal Cakrawala Hukum,13 (1), 2017.

Oey Valentino Winata, Wisnu Aryo Dewanto, "BatasanTerhadap Imunitas Advokat Yang Diperluas Berdasarkan Putusan Mahkamah Konstitusi Nomor 26/PUU-XI/2013”, DiH: Jurnal Ilmu Hukum 16 (1), 2020. DOI: https://doi.org/10.30996/dih.v16i1.2974

Patria Palgunadi, "Reposisi Bantuan Hukum Secara ProbonoOleh Organisasi Bantuan Hukum Dalam Kajian Undang-Undang Nomor 16 Tahun 2011 Tentang Bantuan Hukum”, Jurnal USM Law Review 1 (2), 2018.

DOI : $\underline{10.26623 / j u l r . v 1 i 2.2253}$

Sardinata, Hambali Thalib, Mulyati Pawennei, "Hak Imunitas Advokat Dalam Menangani Perkara”, Jurnal Lex Generalis 2 (3), 2021.

DOI: https://doi.org/10.52103/jlg.v2i3

\section{Peraturan Perundang-undangan}

Undang-Undang Dasar 1945

Kitab Undang Uindang Hukum Perdata

Undang-Undang Nomor 18 Tahun 2003 Tentang Advokat

Kode Etik Advokat Indonesia

MoU PERADI dan KAPOLRI No. B/7/II/, No. 002/PERADI-DPN/Mou/II/2012

IBA Standart for the independence of the Legal Profession

\section{Majalah}

Ahmad Zaenal Fanani, “Berpikir Falsafati Dalam Putusan Hakim”, Majalah Varia Peradilan No. 304, Maret 2011.

\section{Internet}

Sakhiyatu Sova, Tiga Nilai Dasar Hukum Menurut Gustav Radbruch, http://www.scrid.com/doc/170579596/Tiga-Nilai-Dasar-Hukum-MenurutGustav-Radbruch\#scridb

Kamus Bahasa Indonesia, http://m.artikata.com/arti-339692-manfaat.html, http://lammarasi-sihaloho.blogspot.com/2011/04/kode-etik-advokat.html $\operatorname{tgl} 23$ februari 2018

R. Rumapea, Pengaturan Hukum Tentang Pelaksanaan Hak Imunitas di Indonesia, www.http//repository.usu.ac.id. 